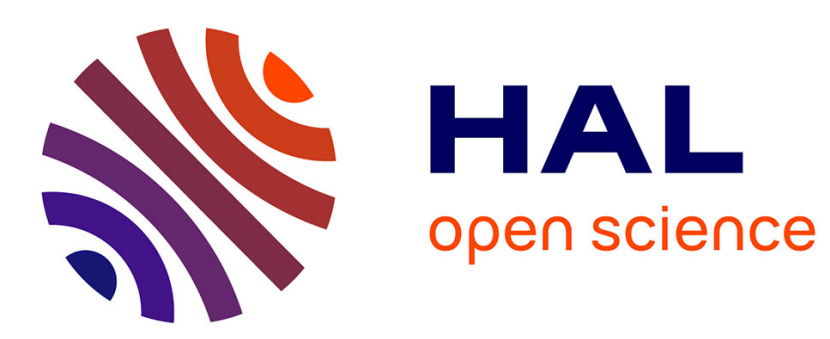

\title{
Fractional-Order Information in the Visual Control of Locomotor Interception
}

\author{
Reinoud J. Bootsma, Rémy Casanova, Frank T J M Zaal
}

\section{To cite this version:}

Reinoud J. Bootsma, Rémy Casanova, Frank T J M Zaal. Fractional-Order Information in the Visual Control of Locomotor Interception. Perception, 2019, 48 (1_suppl), pp.187-187. $10.1037 / \mathrm{xhp0000162}$. hal-02479626

\section{HAL Id: hal-02479626 \\ https://hal-amu.archives-ouvertes.fr/hal-02479626}

Submitted on 2 Mar 2020

HAL is a multi-disciplinary open access archive for the deposit and dissemination of scientific research documents, whether they are published or not. The documents may come from teaching and research institutions in France or abroad, or from public or private research centers.
L'archive ouverte pluridisciplinaire HAL, est destinée au dépôt et à la diffusion de documents scientifiques de niveau recherche, publiés ou non, émanant des établissements d'enseignement et de recherche français ou étrangers, des laboratoires publics ou privés. 


\section{Fractional-Order Information in the Visual Control of Locomotor Interception}

Reinoud Bootsma ${ }^{1}$, Remy Casanova ${ }^{1}$ and Frank Zaal $^{2}$

${ }^{1}$ Institute for Movement Sciences, Aix-Marseille University, France

${ }^{2}$ Center for Human Movement Sciences, University of Groningen, the Netherlands

Work on locomotor interception - contacting a moving target by means of whole-body displacement - has converged onto a limited set of strategies. During pursuit, the agent continuously moves in the current direction of the target (nulling angular eccentricity), while interception is accomplished by keeping the target's bearing constant (nulling angular velocity). For catching fly balls, a strategy of nulling angular acceleration has been proposed. Available information is thus generally conceived as (and limited to) integer-order time derivatives (pos=0, vel=1, acc $=2$ ). In this contribution, we will present experimental work demonstrating that observed behaviour indicates situation-dependent reliance on information of intermediate order, requiring combinations of Orders 0 and 1 for straight and Orders 1 and 2 for curving target trajectories. We argue that such (mostly unprincipled) combinations might advantageously be replaced with a fractional-order conception of information.

Abstracts of the 41st European Conference on Visual Perception (ECVP) 2018 Trieste

Published in Perception, 2019, Vol. 48(Suppl. 1), p. 187 (DOI: 10.1177/0301006618824879) 